\title{
Other Important Collectors and Donors
}

The names of the founders and later members of the board of directors of the Minneapolis Society of Fine Arts are synonymous with a listing of important early Twin Cities art collectors. Minneapolis names include William Whitney, James S. Bell, John Van Derlip, Edward Gale, Frank H. Peavey, W. H. Dunwoody, Martin B. Koon, Sumner T. McKnight, William Chute, Thomas Lowry, Charles A. Pillsbury, Frederick Pillsbury, Alfred F. Pillsbury, William D. Washburn, Clinton Morrison, and Mrs. Putnam McMillan. Many of these collectors were among the earliest benefactors of the Society. Van Derlip donated money, Clinton Morrison donated the land upon which the museum was built, and McMillan donated decorative arts.

One of the founding trustees of the Minneapolis Institute of Arts was Herschel V. Jones (1861-1928) the owner of the Minneapolis Journal newspaper. His collecting interest was prints. Over the years he assembled a collection of many thousand prints dating from the fifteenth to the twentieth century, containing the entire spectrum of the graphic arts. ${ }^{123}$ The highlight of his efforts was the purchase in Oregon of the William M. Ladd collection. The Ladd collection of prints included over 150 Rembrandts, 119 Dürers, and selections by Piranesi, de Ribera, and Kandinsky.124 Jones' 1916 gift to the Minneapolis Institute of Arts, then valued at over $\$ 600,000$, was considered so important that the museum's first separate curatorial department was established to deal with it. ${ }^{\mathbf{1 2 5}}$ According to art historian Lisa Dickinson Michaux, the scope of this gift cannot be understated:

The opportunity for a newly established Midwestern museum to display original works by such masters as Rembrandt and Dürer, while also exhibiting recent trends in the graphic arts, brought Minneapolis acclaim and respect. The Ladd prints were instrumental in bringing the museum national, and even international, recognition at an early stage in its existence..$^{\mathbf{1 2 6}}$

What follows are summary descriptions of the art collections of various other early Twin Cities collectors. Their selection of paintings should presumably be judged in the context of what was then fashionable and, indeed, affordable. Taking the case of French artist Julien Dupré (1851-1910), whose paintings were found in many of these collections, as an example, one can see that while Dupré witnessed fame and fortune during his lifetime, yet his works were to be shunned by the art world during much of the ensuing twentieth century. ${ }^{\mathbf{1 2 7}}$ William-Adolphe Bouguereau is another example of an artist successful in his lifetime, but less valued in later decades. The critical assessment of such works today must consider that tastes do change and even change again. 
Martin B. Koon was a Minneapolis attorney and judge active in the formation of the Minneapolis Society of Fine Arts in 1883. His art collection was principally composed of contemporary American paintings, including one which he took particular pride in, Luxembourg Garden at Twilight, by John Singer Sargent (18561925). ${ }^{128}$

W. H. Dunwoody, who achieved his wealth through grain milling, owned several canvases of Constant Troyon (1810-1865), including Landscape with Cattle, and Feeding the River. These oils, as well as Child with Cherries, later known as Yvonne, (1895) is William-Adolphe Bouguereau were subsequently donated to the Minneapolis Institute of Arts. ${ }^{129}$

A Minneapolis newspaper, the Journal, in a series of 1903 articles cited below described the lives of the rich and famous, their homes, and their art collections.

Frank $\mathrm{H}$. Peavey, who made his fortune in the grain elevator business, owned paintings by twenty foreign and nine American artists. The Minneapolis Journal noted that "the paintings that adorn the walls of the Peavey residence are exquisitely selected." His collection included works by Jules Breton, Charles Daubigny, Alexis Fournier, William-Adolphe Bouguereau and Jean-Léon Gérōme. "The Bath which shows an eastern interior, with the marbles that Jean-Léon Gérōme is so fond of painting, is probably the only example of his work in Minneapolis." ${ }^{130}$ Gérōme (1824-1904) was a French painter whose work included historical subjects, Greek mythology and Orientalist subjects.

Thomas Lowry, owner of extensive urban real estate and founder of the Twin Cities streetcar systems, purchased most of his collection in 1886 in Europe, often from the artists' studios, Bouguereau, and others from the Salon exhibits. His collection included 33 works of art, including those of Murillo, Millet and Gabriel Max. ${ }^{131}$ Lowry's home had an art gallery. ${ }^{132}$

Sumner T. McKnight, whose fortune came from lumber and real estate ventures, acquired his collection in the early years of the twentieth century. His collection contained works of sixteen artists, including those by Julien Dupré, Constant Troyon, and George Inness. ${ }^{133}$

Paintings by ten artists hanging in the James $\mathrm{S}$. Bell residence "were purchased because the beauty of each painting appealed to their owner." According to the Minneapolis Journal the gem of the collection is probably the Daubigny, purchased recently at the Angelo sale in Philadelphia. It was called Washing on the Seine. Charles-François Daubigny (1817-1878) was an important French artist of the Barbizon school. His work includes a number of paintings of the Seine River, so it is not possible to identify further, with certainty, the picture acquired by James S. Bell. Also in the Bell collection were several Charles M. Russell (1864-1926) paintings of western scenes. ${ }^{134}$ Bell was involved in various flour milling businesses.

Another important Minneapolis collector was William D. Washburn, a onetime U. S. Senator from Minnesota, who made his fortune in grain milling 
and lumbering. The city block upon which his Minneapolis mansion, called "Fairoaks," was located would eventually become the city park across from the Minneapolis Institute of Arts. Washburn was generous in lending art from his collection to local exhibitions.

The fortunes of the Pillsbury family came from flour milling, and allowed the building of three important collections. The eldest, Charles A. Pillsbury, was said to be interested in "adorning his walls with the work of good artists." While he owned works by Bouguereau, and Dupré he also favored, among his twentyfive canvasses, the works of American artists. The works of twenty-four artists in the residence of Frederick C. Pillsbury included those of many American artists, including William T. Richards, M. Wright, J. C. Brown, George McCord and James Hart. Reporter Ruth Danenbaum noted that John S. Pillsbury, on the other hand, was said to be interested only in "beautifying his home." His oil paintings included works by Julian Dupré, and a "portrait of Rembrandt, attributed to Rembrandt... a strong picture with all of the Rembrandt coloring." ${ }^{135}$

The Reverend John Wright became Rector of St. Paul's Episcopal Church in 1887, which was then located at Ninth and Olive streets in St. Paul, Wright was described in Episcopal Church documents as "a man of deep piety and wide reading, who is showing Americans that in the West something more can be done than make exceedingly good railways and flour..." ${ }^{136}$ In addition to art, Wright amassed a large collection of bibles and prayer books; he was an author on many religious subjects; and he lectured extensively on other subjects, including Egyptology. Being a man of the cloth, Reverend Wright clearly did not have the financial assets of the capitalists described in the previous paragraphs, but he exhibited the painting The Mystic Marriage of St. Catherine (circa 1500-1510) by the Italian Renaissance artist Antonio da Correggio (1489-1534) at the 1890 Harvest House Festival in St. Paul (discussed in a later chapter) which attracted significant local interest. A newspaper reporter had the following to say:

The picture which attracts the most interest, probably, is a small one loaned by Dr. Wright, rector of St. Paul's, a genuine Correggio... It is a marriage of Catherine and represents the Virgin holding the blessed Child, who leans forward to place upon the finger of the young girl the ring which wedded Him to Her and His work... The picture is a beautiful and rare one, valued at thousands of dollars. It has changed hands but twice since it left the possession of the Pepoli family, who held it in Bologna for over 300 years. ${ }^{137}$

A comparison of these affluent Twin Cities collectors, such as those mentioned previously, to explain what they selected for their collections, and why, is impossibly complicated. Nearly all of the families of these collectors came to Minneapolis from Eastern cities. As such they presumably had some awareness 


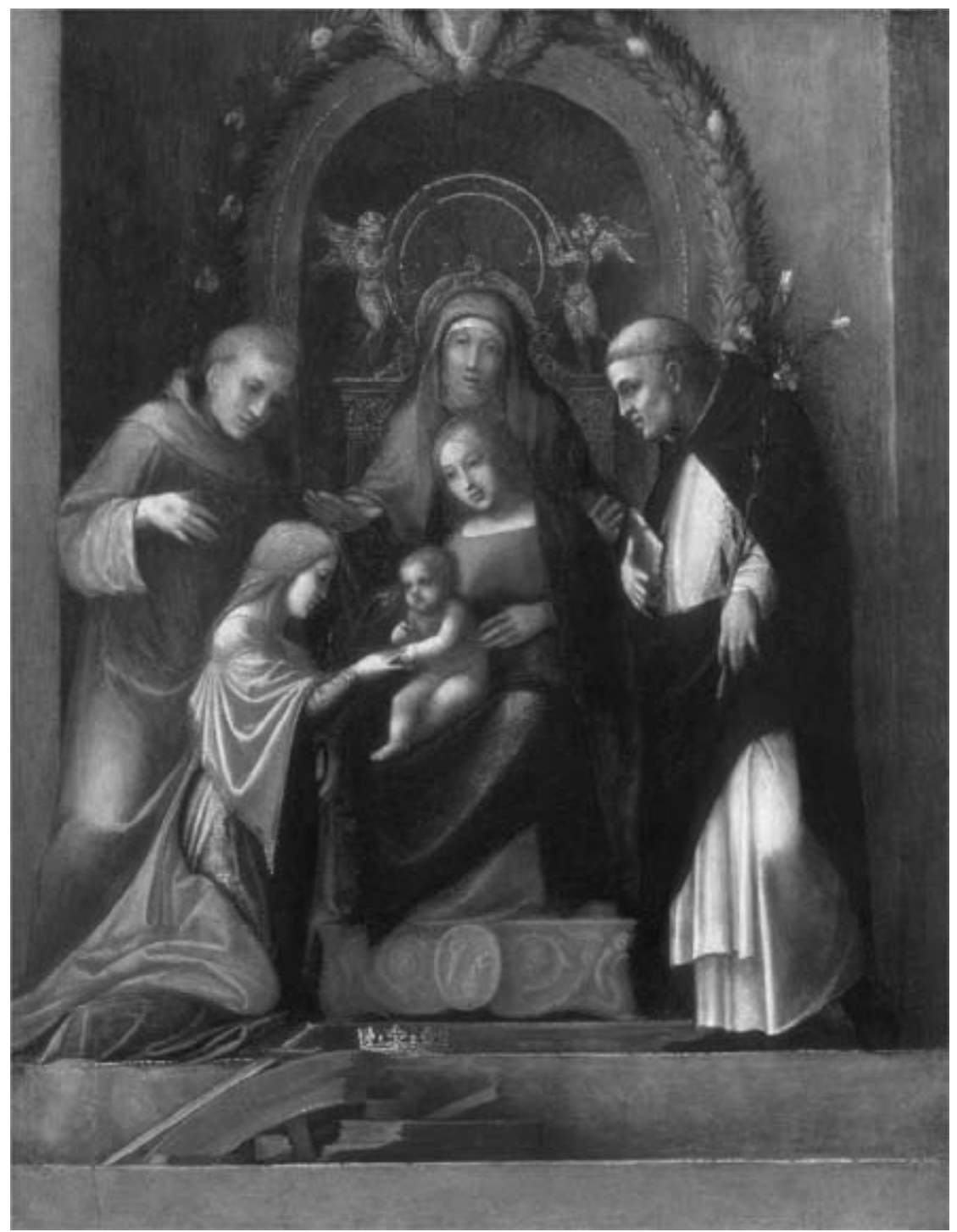

Fig. 7.1 The Mystic Marriage of St. Catherine, by Antonio da Correggio, circa 1500-1510 Courtesy of the National Gallery of Art, Washington, D. C.

of the place of the fine arts in their earlier communities. Their collections usually included portraits, landscapes, animals, and scenes of the rural poor. Almost no religious scenes are noted, perhaps because they generally were of the Protestant persuasion. 
But such comparisons quickly become blurred. More than a century has passed, and this highly conceptual question is not one in which third and fourth generation heirs are comfortable with, and few written records on the subject are available. Each of these collectors had his own particular background: education, culture, religion, travel, and family interests. It would not be productive to delve further than this.

These collectors mainly purchased from New York dealers, often selecting works that had been awarded prizes in the French salons. While Walker and Hill certainly set the standard, there were also different avenues and influences to guide the other local collectors, as the following chapters demonstrate. 